\title{
PERAN SERTA ONDOFOLO DALAM GANTI RUGI TANAH UNTUK KEPENTINGAN UMUM YANG BERKEADILAN
}

\author{
Retno Mumpuni, Imam Koeswahyono, Rachmad Syafaat \\ Program Studi Magister KenotariatanUniversitas Brawijaya \\ Jl. M.T Haryono No.167 Malang \\ email :retnomumpuni3110@gmail.com
}

\begin{abstract}
This paper aims to describe the process of compensation in the procurement of land for the public interest in the expansion of Sentani Airport, the legal implication that Ondofolo is not involved in the process of providing compensation for the procurement of land for public purposes, and the correct way of putting the role or position of Ondofolo in procurement of land for the just public interest. The study used a sociological juridical approach. The process of providing compensation in the procurement of land for public purposes in the expansion of a sentani airport involves ondofolo. The legal implications if Ondofolo not involved in the process of compensation for land acquisition for public purposes is a violation of the provisions of Article 43 of Law No. 21 of 2001 on Special Autonomy for Papua which has resulted in the validity of the decision of the government in acquiring the land. The role of Ondofolo in the procurement of land for the public interest is limited to affect the behavior of people in order to work together in realizing mutually agreed objectives for the creation of justice and the guaranteed rights of indigenous peoples both customary and constitutional of the Republic of Indonesia as long as it does not violate the rules applicable .
\end{abstract}

Keyword: ondofolo, public interest, special autonomy, indigenous community, land procurement

\begin{abstract}
Abstrak: Tulisan ini bertujuan untuk mendeskripsikan proses pemberian ganti rugi dalam pengadaan tanah untuk kepentingan umum dalam perluasan Bandar Udara Sentani, implikasi hukum jika Ondofolo tidakd ilibatkan dalam proses pemberian ganti rugi atas pengadaan tanah untuk kepentingan umum, dan cara yang benar dalam meletakkan peran atau posisi Ondofolo dalam pengadaan tanah bagi kepentingan umum yang berkeadilan. Kajian menggunakan pendekatan yuridis sosiologis. Proses pemberian ganti rugi dalam pengadaan tanah untuk kepentingan umum dalam perluasan bandar udara sentani melibatkan ondofolo. Implikasi hukum jika Ondofolo tidak dilibatkan dalam proses pemberian ganti rugi atas pengadaan tanah untuk kepentingan umum adalah pelanggaran terhadap ketentuan Pasal 43 UU Nomor 21 Tahun 2001 tentang Otonomi Khusus Papua yang mengakibatkan tidak sahnya keputusan pemerintah dalam pengadaan tanah tersebut. Peran Ondofolo dalam pengadaan tanah untuk kepentingan umum adalah sebatas mempengaruhi tingkah laku orang-orang supaya dapat bekerjasama dalam mewujudkan tujuan yang disepakati bersama demi terciptanya keadilan dan terjaminnya hak-hak masyarakat adat baik secara adat maupun secara konstitusional Republik Indonesia selama tidak melanggar aturan yang berlaku.
\end{abstract}

Kata kunci : Ondofolo, kepentingan umum, otonomi khusus, masyarakatadat, pengadaantanah.

Tanah sebagai bagian dari bumi disebutkan dalam Pasal 4 Ayat (1) Undang-UndangNomor 5 Tahun 1960 Tentang Pokok-Pokok Agraria (selanjutnya disebut UUPA) yaitu atas dasar hak menguasai dari negara sebagai yang dimaksud dalam Pasal 2 UUPA ditentukan adanya macam hak atas permukaan bumi, yang disebut tanah yang dapat diberikan kepada dan dipunyai oleh orang-orang baik sendiri maupun bersama-sama dengan orangorang lain serta badan-badan hukum (Santoso, 2012). Tanah merupakan salah satu faktor penting bagi keberlangsungan kehidupan manusia. Manusia hidup dan melakukan berbagai aktivitas kesehariannya di atas tanah serta memperoleh bahan pangan dengan memanfaatkan tanah. Bahkan bagi Negara Indonesia tanah merupakan 
salah satu modal utama bagi kelancaran pembangunan (Cahyo, B.T., 1983).

Masalah tanah adalah masalah yang menyangkut hak rakyat yang paling dasar. Tanah disamping mempunyai nilai ekonomis juga berfungsi sosial, oleh karena itulah kepentingan pribadi atas tanah tersebut dikorbankan guna kepentingan umum. Ini dilakukan dengan pelepasan hak atas tanah dengan mendapat ganti rugi yang tidak berupa uang semata akan tetapi juga berbentuk tanah atau fasilitas lain.Hal ini berarti nilai ekonomis hak atas tanah akan berbeda dengan hak yang melekat pada tanah tersebut, dengan demikian ganti rugi yang diberikan atas tanah itu juga menentukan berapa besar yang harus diterima dengan adanya hak berbeda itu. Namun demikian negara mempunyai wewenang untuk melaksanakan pembangunan sebagaimana diatur dalam peraturan perundangundangan baik dengan pencabutan hak maupun dengan pengadaan tanah.

Masalah pengadaan tanah sangat rawan dalam penanganannya, karena di dalamnya menyangkut hajat hidup orang banyak, apabila dilihat dari kebutuhan pemerintah akan tanah untuk keperluan pembangunan, dapatlah dimengerti bahwa tanah negara yang tersedia sangatlah terbatas.

Oleh karena itu satu-satunya cara yang dapat ditempuh adalah dengan membebaskan tanah milik masyarakat, baik yang telah di kuasai dengan hak berdasarkan hukum Adat maupun hak-hak lainnya menurut UUPA. Proses pengadaan tanah tidak akan pernah lepas dengan adanya masalah ganti rugi, maka perlu diadakan penelitian terlebih dahulu terhadap segala keterangan dan data-data yang diajukan dalam mengadakan taksiran pemberian ganti rugi. Sehingga apabila telah tercapai suatu kesepakatan mengenai bentuk dan besarnya ganti rugi, maka baru dilakukan pembayaran ganti rugi kemudian dilanjutkan dengan pelepasan atau penyerahan hak atas tanah yang bersangkutan.

Indonesia adalah negara yang terdiri dari berbagai pulau dari Sabang sampai Merauke, dimana setiap pulau memiliki kultur dan Adat istiadat yang berbeda-beda. Keanekaragaman ini pun merupakan ciri khas dari masing-masing masyarakat hukum Adat, salah satunya tanah Ulayat. Tanah merupakan tempat berpijak dan berkembang sekelompok komunitas masyarakat Adat yang mempunyai aturan dan sistem tersendiri. Tanah mempunyai peranan penting dalam kaitannya dengan kelangsungan hidup manusia selain sebagai tempat tinggal, juga sebagai tempat bercocok tanam dan berkebun. Disamping itu tanah Ulayat sangat erat kaitannya dengan budaya religi dan sosial suatu masyarakat Adat, dimana cara perolehan secara turun temurun menyebabkan tanah Ulayat mempunyai histori yang melekat pada kaum masyarakat hukum Adat.

Tanah ulayat mempunyai peranan yang sangat penting dimana didalam kehidupan masyarakat hukum adat, tanah ulayat merupakan milik leluhur yang harus dijaga, dirawat dan dipelihara secara bergantian sampai generasi berikutnya, yang memiliki hak atas tanah Ulayat untuk menguasai seluruh tanah beserta isinya yang berada dalam kawasan wilayah hukumnya (Sudiyat, 1978).Hak Ulayat diatur dalam Pasal 3 UndangUndang Pokok Agraria yang bunyinya sebagai berikut : Dengan mengingat ketentuan-ketentuan dalam Pasal 1 dan 2, pelaksanaan hak Ulayat dan hak-hak yang serupa dari masyarakat-masyarakat hukum Adat, sepanjang menurut kenyataannya masih ada, harus sedemikian rupa sehingga sesuai dengan kepentinga nasional dan Negara, yang berdasar atas persatuan bangsa serta tidak boleh bertentangan dengan Undang-Undang dan peraturan lain yang lebih tinggi (Harsono, 2013).

Pada masyarakat hukum Adat, tanah mempunyai peranan yang sangat penting, hal ini dapat dilihat dengan adanya pengaruh pranatapranata diluar persekutuan hukum Adat yang memberikan perubahan ukuran nilai terhadap fungsi manfaat hak atas tanah Adat oleh setiap kelompok masyarakat hukum Adat itu sendiri. Selain mempunyai nilai sosial, tanah juga mempunyai nilai ekonomi, artinya tanah Adat tersebut dapat dialihkan hak dan kepemilikannya oleh penguasa hukum Adat kepada pihak lain diluar masyarakat hukum Adat tersebut dengan cara pelepasan hak atas tanah Adat, sehingga menimbulkan banyak permasalahan yang ditimbulkan dari proses pelepasan tanah Adat tersebut menjadi tanah milik instansi Pemerintah.

Konflik tanah Ulayat menjadi hal yang sukardiselesaikan bagi investor dan kendala terbesar bagi pemerintah dalam melaksanakan pembangunan sebagaimana diamanatkan dalam Pasal 18 Huruf B Ayat (2) UUD 1945, sementara dipihak rakyat, pelepasan hak atas tanah Adat/ Ulayat, tidak berbanding lurus terhadap peningkatan kesejahteraan dan kualitas hidup. 
Sebagian besar masyarakat Papua hidup dalam kemiskinan, keterbelakangan dan terpinggirkan oleh konsep pembangunan yang terfokus pada peningkatan kesejahteraan birokrasi. Realitas objektif saat ini, populasi penduduk bertambah, tanah hunian bertambah dan tanah bercocok tanam berkurang drastis. Kondisi ini diperburuk dengan perkembangan social-ekonomi masyarakat yang relatif lamban dan tidak terbina secara baik. Sumber daya manusia tidak berkembang secara pesat, maka praktis masyarakat terpinggirkan dari seluruh aksebilitas pembangunaan social, ekonomi dan politik didaerah dan nasional.

Undang-Undang Nomor 2 Tahun 2012 tentang Pengadaan Tanah Untuk Kepentingan Umum memiliki peraturan-peraturan pelaksana antara lain Peraturan Presiden Nomor 71 Tahun 2012 tentang Penyelenggaraan Pengadaan Tanah Untuk Kepentingan Umum, serta Peraturan Kepala Badan Pertanahan Nasional Nomor 5 Tahun 2012, Peraturan Kementerian Dalam Negeri Nomor 72 Tahun 2012 dan Peraturan Kementerian Keuangan Nomor 13 Tahun 2013 sebagai pelaksanaan UU 2 Tahun 2012 itu sendiri sebagai dasar hukum pengadaan tanah untuk kepentingan umum.

Merupakan kewenangan Pemerintah dalam hal pengadaan tanah bagi pelaksanaan untuk kepentingan umum untuk menyediakan tanah untuk pembangunan baik sarana pembangunan umum maupun fasilitas-fasilitas sosial lainnya (Yamin, 1971). Hal ini dikarenakan masalah tanah sangat rumit dan berpotensi menimbulkan gejolak, untuk itu diperlukan peranan penting dari Pemerintah daerah dan instansi lain dalam pendekatan ke masyarakat hukum Adat yang bukan bersifat yuridis saja akan tetapi berkaitan juga dengan psikologis (Kelsen, 1961; Sitorus,\&Sebayang, 1996).

Hak ulayat masyarakat hukum adat merupakan kekuasaan tertinggi tetapi tidak bersifat mutlak, selama tidak bertentangan dengan peraturan Undang-Undang Pokok Agraria Nomor 5 Tahun 1960. Pada Pasal 18 UUPA yang menyatakan : Untuk kepentingan umum, termasuk kepentingan bangsa dan negara serta kepentingan bersama dari masyarakat, hak-hak atas tanah dapat dicabut, dengan memberi ganti kerugian yang layak dan menurut cara yang diatur dengan Undang-Undang.

Kewenangan Gubernur selaku Pemerintah Daerah Provinsi dan pelindung hukum terhadap pemilik hak atas tanah tercermin melalui pengaturan mengenai musyawarah, pemberian ganti kerugian, dan pemberian kesempatan untuk mengajukan gugatan ke Pengadilan Tata Usaha Negara maupun ke Pengadilan Negri (Sugiharto, U.S., 2015). Pelaksanaan pembangunan dewasa ini, disamping meningkatkan kesejahteraan masyarakat ternyata menimbulkan permasalanah. Permasalahan tanah yang dihadapi oleh pemerintah dalam pelaksanaan pembangunan diantaranya adalah masalah penyediaan tanah untuk pembangunan itu sendiri, karena tanah negara yang dikuasai oleh negara sudah sangat terbatas bahkan sudah tidak ada sama sekali (Soimin, S., 2001).

Pasal 1 Angka 2 Peraturan Presiden Nomor 71 Tahun 2012 menentukan bahwa pengadaan tanah adalah kegiatan menyediakan tanah dengan cara memberikan ganti kerugian yang layak kepada pihak yang berhak. Kemudian didalam Pasal 86 Peraturan Presiden Nomor 71 Tahun 2012 menentukan bahwa apabila tidak terjadi suatu kesepakatan didalam musyawarah dalam menentukan bentuk dan besarnya ganti kerugian maka panitia pengadaan tanah akan menitipkan ganti rugi kepada Ketua Pengadilan Negeri yang wilayah lokasi pembangunan untuk kepentingan umum.

Oleh karenanya khusus untuk masalah pembangunan untuk kepentingan umum menurut Pasal 18 Undang-Undang Nomor 5 Tahun 1960 tentang Dasar pokok-pokok Agraria, dimana dinyatakan bahwa untuk kepentingan umum, termasuk kepentingan bangsa dan negara serta kepentingan bersama dari rakyat, hak-hak atas tanah akan dicabut, dengan memberi ganti kerugian yang layak dengan cara yang diatur dalam Undang-Undang. Dalam Pasal 7 Ayat 2 Peraturan Pemerintah Nomor 38 Tahun 2007 tentang pembagian urusan pemerintahan antara Pemerintahan Daerah Propinsi dan Pemerintahan Daerah Kabupaten/Kota salah satunya adalah pertanahan.

Pelaksanaan pengadaan tanah tersebut dilakukan dengan memperhatikan peran dan fungsi tanah dalam kehidupan manusia serta prinsip penghormatan terhadap hak-hak yang sah atas tanah. Dengan demikian pengadaan tanah untuk kepentingan umum diusahakan dengan cara yang seimbang dan ditempuh dengan jalan musyawarah langsung dengan para pemegang hak atas tanah.

Dalam ketentuan Pasal 40 UU Pengadaan Tanah Demi Kepentingan Umum, bahwa pemberian ganti rugi harus diberikan langsung 
kepada pemilik tanah. Masalah kemudian muncul dalam proses pengadaan tanah demi kepentingan umum dalam perluasan Bandar Udara Sentani di Papua. Dimana terjadi gugatan dalam proses pengadaan tanah yang mengesampingkan peran Ondofolo. Ondofolo sendirimerupakan kepala Adat yang memimpin dan membawahi kepala suku yang terdapat di wilayah masyarakat hukum adat di sekitar Bandar Udara Sentani di Papua.Dimana menurut Undang-Undang Otonomi Khusus Papua Nomor 21 Tahun 2001 (UU Otonomi Khusus Papua) Pasal 43 merupakan pihak yang berwenang dalam pengesahan tanah Adat, sedangkan dalam pelaksanaan UU Nomor 2 Tahun 2012 tentang Pengadaan Tanah Demi Kepentingan Umum, Dalam ketentuan Pasal 40 bahwa pemberian ganti rugi harus diberikan langsung kepada pemilik tanah dengan mengedepankan pembayaran ke pemilik langsung. Dimana jika Ondofolo dalam kedudukannya yang seharusnya melindungi kepentingan-kepentingan masyarakat hukum Adat secara umum dan pemilik tanah Adat secara khususnya tidak diikutkan dalam proses tersebut, besar kemungkinan akan terjadi masalah-masalah yang tidak diinginkan. Seperti nilai ekonomis tanah yang tidak sesuai dengan seharusnya, kemungkinan pemberian ganti kerugian yang tidak tepat sasaran atau salah kepemilikan dan lain-lain.

\section{METODE}

Kajian ini disusun menggunakanmetode yuridis empiris, yang dilakukan dengan pendekatan yuridis sosiologis di Kabupaten Sentani, yang didukung dengan data primer berupa data yang diperoleh langsung dari sumbernya, baik melalui wawancara, observasi maupun laporan dalam bentuk dokumen tidak resmi yang kemudian diolah dan data sekunder berupa peraturan perundangundangan terkait, buku-buku, Jurnal ilmiah baik Online maupun Non Online dan Literatur lainnya yang berhubungan dengan topik pembahasan.

\section{HASIL DAN PEMBAHASAN}

Indikasi Proses Pemberian Ganti Rugi Dalam Pengadaan Tanah Untuk Kepentingan Umum Dalam Perluasan Bandar Udara Sentani Mengabaikan Peran Serta Ondofolo

Perolehan tanah adalah suatu tahapantahapan kegiatan yang harus dilalui oleh seseorang, badan hukum, instansi pemerintah untuk memperoleh hak atas tanah bagi kegiatan pembangunan. Hukum tanah nasional menyediakan cara memperoleh tanah, yaitu:(a) status tanah yang tersedia, tanahnya merupakan tanah negara atau tanah hak, (b) apabila tanah hak, apakah pemegang haknya bersedia atau tidak menyerahkan hak atas tanahnya tersebut, dan (c) apabila pemegang hak bersedia menyerahkan atau memindahkan haknya, apakah yang memerlukan tanah memenuhi syarat sebagai pemegang hak atas tanah yang bersangkutan atau tidak memenuhi syarat (Harsono, 2005).

Khusus untuk pengadaan tanah bagi kepentingan umum yang dilaksanakan oleh Pemerintah ataupun Pemerintah Daerah dilakukan dengan cara pelepasan atau penyerahan hak atas tanah; atau Pencabutan hak atas tanah. Sedangkan pengadaan tanah selain untuk kepentingan umum yang dilaksanakan oleh Pemerintah atau Pemerintah Daerah, dalam hal ini dilaksanakan oleh pihak swasta maka dilaksanakan dengan jual-beli, tukar-menukar, atau cara lain yang disepakati secara sukarela oleh pihak-pihak yang bersangkutan.

Prinsip-prinsip kriteria kepentingan umum dapat diuraikan lebih rinci, yakni meliputi sifat kepentingan umum, bentuk kepentingan umum, dan ciri-ciri kepentingan umum. Demikian metode penerapan tiga aspek tersebut sehingga criteria kepentingan umum dapat diformulasikan secara pasti, adil dan dapat diterima oleh masyarakat.Sifat dan bentuk kepentingan umum pengadaan tanah dapat disimpangi dalam penafsirannya ataupun dalam operasionalnya sehingga sangat penting dalam tulisan ini dibahas tentang karakteristik yang berlaku sehingga kegiatan kepentingan umum benar-benar untuk kepentingan umum, dan dapat dibedakan secara jelas dengan kepentingankepentingan yang bukan kepentingan umum. Dengan kata lain, akan dibahas hal-hal yang paling prinsip sehingga suatu kegiatan benar-benar untuk kepentingan umum (Sutedi, 2011).

Tujuan dan perolehan tanah yang dilakukan pemerintah sepenuhnya untuk kepentingan umum dalam rangka mewujudkan kesejahteraan masyarakat. Sehingga manakala pemerintah membutuhkan tanah masyarakat haruslah dilakukan dengan cara-cara atau sesuai dengan prosedur hukum sehingga tujuan untuk mewujudkan kesejahteraan dan kepentingan umum tidak bersebrangan dengan pemilik tanah yang berhak atas tanah tersebut. 
Dalam setiap pengadaan tanah untuk kepentingan pembangunan hampir selalu muncul rasa tidak puas, di samping tidak berdaya, dikalangan masyarakat yang hak atas tanahnya terkena proyek tersebut. Masalah ganti rugi merupakan isu sentral yang paling rumit penanganannya dalam upaya pengadaan tanah oleh pemerintah dengan memanfaatkan tanahtanah hak.Dalam penelitian ini yang akan menjadi bahasan adalah proses pemberian ganti kerugiannya. Di berbagai negara berkembang tersedia indeks alternatif yang dapat digunakan sebagai pedoman untuk menentukan besarnya ganti rugi. Di Brazil, faktor taksiran nilai untuk keperluan pemungutan pajak, lokasi, keadaan tanah (terpelihara/tidak), nilai pasar selama lima tahun terakhir dari hak atas tanah lain yang sebanding menjadi bahan pertimbangan penentuan besarnya ganti rugi.Dalam kaitannya dengan masalah ganti rugi, tampaklah bahwa menentukan keseimbangan antara kepentingan perseorangan dengan kepentingan umum itu tidak mudah (Soemardjono, 2001).

Proses pengadaan tanah perluasan Bandar Udara Sentani pada awalnya tidak memiliki kendala hingga sampai pada proses persiapan mengenai data siapa- saja yang berhak menerima ganti kerugian. Pengadaan tanah tersebut pada saat ini dalam Tahap Pelaksanaan Pembebasan Tanah yakni Pelelangan Tim Appraisal sesuai dengan Peraturan Menteri Keuangan Nomor 13/PMK.02/2013 Tentang Biaya Operasional dan Biaya Pendukung Penyelenggaraan Pengadaan Tanah bagi Pembangunan untuk Kepentingan Umum yang bersumber pada APBN. Pada tanggal 30 November 2015 diadakan Rapat di Kantor BPN Kabupaten Jayapura yang dihadiri oleh Masyarakat Pemilik Tanah Adat, Ondofolo Ifar Besar, Kepala BPN Kabupaten Jayapura dan sebagai Pimpinan Rapat adalah Kepala Kantor Wilayah BPN Jayapura. Hasil Rapat yang terteradalamSurat Laporan Kronologis Permasalahan Tanah Pengadaan TA. 2015, Nomor UM.002/ .25.II/BU.STN-2016 tertanggal 25 Februari 2016 ditujukan kepada Direktur Jenderal Perhubungan Udaraini antara lain : (a) masyarakat adat yang diwakili Ondofolo Ifar Besar sepakat dengan besaran Harga Rp.1.250.000,-, dan (b) masyarakat bersepakat bila pada tanggal 2 Desember 2015 dilakukan proses Validasi Tanah di Lapangan Oleh Tim BPN atas peta bidang yang telah dibuat sebelumnya dari hasil pengukuran lapangan pada tanggal 24 November 2014.
Pemerintah selalumelibatkan Ondofolo dalampengadaantanah, hanya saja terdapat pertentangan pendapat mengenai siapa yang lebih berhak terhadap ganti kerugian tersebut menurut Ondofolo sehingga hingga tulisan ini dibuat. Pengadaan Tanah Untuk Kepentingan Umum Demi Perluasan Bandara Sentani ini belum selesai karena masih terdapat proses hukum di pengadilan terkait siapa yang berhak terhadap ganti kerugian. Hal tersebut terjadi karena terdapat perbedaan siapa pemilik tanah yang sah menurut pemerintah dan masyarakat adat yang mendiami dengan pendapat Ondofolo.

Menurut teori penegakkan hukum maka proses pengadaan tanah untuk keentingan umum dalam hal ini pelebaran Bandar Udara Sentani tidak melanggar aturan apapun, karena yang menarik diri dari prosesnya adalah Ondofolo sendiri dengan pertimbangan keadilan menurutnya, sehingga tidak terjadi pelanggaran terhadap ketentuan yang mengatur perlindungan terhadap hak-hak masyarakat adat Pasal 43 UU Nomor 21 Tahun 2001 tentang Otonomi Khusus Papua walaupun memang hingga penelitian ini dilakukan telah sampai pada tahap pemberian ganti kerugian, namun di gugat karena dianggap pihak yang menerima ganti kerugian bukanlah si pemilik tanah yang sebenarnya.

\section{Implikasi Hukum Jika Ondofolo Tidak Dilibatkan Dalam Proses Pemberian Ganti Rugi Atas Pengadaan Tanah Untuk Kepentingan Umum Pada Perluasan Bandara Udara Sentani Di Provinsi Papua}

Hukum adat merupakan sumber utama dalam pembangunan Hukum Tanah Nasional. Ini berarti antara lain bahwa pembangunan Hukum Tanah Nasional dilandasi konsepsi hukum adat, yang dirumuskan dengan kata-kata komunalistik Religius, yang artinya memungkinkan penguasaan tanah secara Individual, dengan hak-hak atas tanah yang bersifat pribadi, sekaligus mengandung kebersamaan (Harsono, 2005). Sehingga hal demikian berarti bahwa kepemilikan tanah secara adat berlaku secara individual dan turun temurun dalam lingkungan masyarakat adat itu saja.

Dalam konteks perlindungan hukum terhadap masyarakat yang tanahnya diambil untuk kepentigan umum yang secara formal telah dituangkan dalam peraturan perundang-undangan itu terus ditingkatkan perwujudannya secara 
konsekuen dan konsisten. Penghormatan kepada hak dasar manusia semestinya diberikan secara proposional, sebab hukum hanya dalam dan untuk hal-hal yang konkrit. Menurut ketentuan Pasal 18 UUPA menyatakan bahwa "Untuk kepentingan umum, termasuk kepentingan bangsa dan Negara serta kepentingan bersama dari rakyat, hak-hak atas tanah dapat dicabut, dengan memberi ganti rugi yang layak dan menurut cara yang diatur dengan Undang-Undang.”

Dengan menggunakan Pasal 18 ini maka hak atas tanah dapat dicabut oleh Negara dengan syarat tertentu yaitu dengan memberi ganti rugi yang layak dan menurut cara yang diatur dengan Undang-Undang. Proses ini memerlukan prosedur yang panjang dan waktu yang lama, karena melalui Keputusan Presiden (Keppres), atas dasar ketentuan Pasal 27 UUPA. Hak atas tanah hapus karena penyerahan sukarela dengan pelepasan hak. Pelepasan hak atas tanah adalah langkah pertama yang dilakukan dalam pelaksanaan pengadaan tanah. Namun cara ini tidak selalu produktif, dan memiliki nilai jual dengan harga tinggi sehingga kerap terjadi dialog atau musyawarah yang cukup alot antara pemerintah dengan pemilik tanah tersebut, khususnya mengenai pemberian ganti rugi.

Pengadaan tanah hanya dapat dilakukan melalui pemberian ganti rugi atas dasar musyawarah. Menurut teori advokasi dan penyelesaian sengketa, musyawarah disini diartikan sebagai proses atau kegiatan saling mendengar dengan sikap saling menerima pendapat dan keinginan yang didasarkan atas kesukarelaan antara pemegang hak atas tanah dan pihak yang memerlukan tanah, untuk memperoleh kesepakatan mengenai bentuk dan besarnya ganti rugi.Musyawarah dilakukan secara langsung antara pemegang hak atas tanah dengan pihak instansi pemerintah yang memerlukan tanah.

Hak tradisional masyarakat adat bukanlah hak berian. Sehingga tanpa dituliskan di dalam konstitusi maupun dalam bentuk hukum tertulis lainnya yang dibuat oleh negara, hak tradisional masyarakat adat tetap menjadi lembaga yang hidup di dalam masyarakat adat. Dalam wawancara dengan Ondofolo didapati bahwa Ondofolo membawahi 5 (lima) Khose (Kepala Suku). Setiap Khose membawahi 5 (lima) Akhona (kepala keret). Setiap kepala keret membawahi kelompoknya masing-masing. Ondofolo tidak di bawah perintah siapa-siapa lagi. Itu berarti Sang
Penguasa di atas Ondofolo hanya Sang Pencipta. Kami masyarakat adat juga dalam naungan pemerintah daerah kabupaten jayapura dengan diterbitkannya PERDA yang mengatur ondofoloondofolo dan kampung Adat yang diakui oleh pemerintah kabupaten jayapura melalui Surat Keputusan Bupati.

Berdasarkan apa yang diungkapkan Ondofolo diatas, keberadaan masyarakat adat dan hak tradisionalnya merupakan salah satu tema penting dalam masyarakat agraris, bukan masyarakat industri. Dalam konteks Indonesia, keberadaan masyarakat adat (dan hak tradisionalnya) telah memiliki sejarah yang cukup panjang dalam konteks politik hukumdi Indonesia.Dimanasecarahukumberartipemimpinpemimpinadattelahdiakui di hukumpositif Indonesia seperti yang tertuangdalam UU Otsus Papua.

Berkaitan dengan proses pengadaan tanah untuk kepentingan umum dalam hal ini perluasan Bandar udara Sentani yang dilakukan diatas tanah milik masyarakat adat di Papua, sejatinya pemerintah dalam menerapkan aturan hukumnya pun seharusnya tetap memperhatikan nilai-nilai atau aturan adat yang terdapat dalam masyarakat tersebut selama tidak bertentangan dengan peraturan tertulis. Seperti data yang didapatkan dari hasil wawancara dengan Ondofolo mengenai proses pengambilan keputusan penting terhadap aset ondofolo bahwa sanya dikarenakan ondofolo membawahi Khose dan Akhona maka setiap ada keputusan-keputusan penting selalu kami kumpulkan di rumah adat/pendopo (obhe). Setiap keputusan dimintakan pendapat terlebih dahulu kepada para khose, dan setelah itu diputuskan oleh ondofolo. Semua masyarakat ifar besar boleh datang dalam rapat adat tersebut namun hanya para pimpinan adat yang boleh menyampaikan pendapat"

Menurut ketentuan Pasal 40 UU Nomor 2 Tahun 2012, dalam pemberian ganti rugi atas objek pengadaan tanah diberikan langsung kepada pihak yang berhak. Tidak ada ketentuan yang membahas mengenai perwakilan dari masyarakat adat dalam penerimaan ganti kerugian. Sehingga dalam prakteknya pemerintah terkait dalam hal ini langsung memberikan kepada yang berhak. Namun terdapat perbedaan antara yang berhak secara data yuridis dan data normatif yang dimiliki oleh masing-masing kubu secara adat.

Salah satu komitmen dalam pembentukan pemerintahan adalah kerelaan warga untuk taat 
kepada aturan-aturan hukum serta kesediaan untuk mendukung setiap kebijakan yang ditetapkan oleh pemerintah, sedangkan pemerintah harus memberikan pelayanan yang terbaik kepada masyarakat. Hal ini sesuai dengan pendapat Rousseaudalam LAN (1997: 5)yang menyatakan bahwa : “... masyarakat telah menyerahkan kewenangannya kepada pemerintah untuk di atur dan dilayani oleh pemerintah ... ". Disinilah akan diharapkan pemerintahan yang ada mendapat legitimasi dari pihak yang diperintah.

Satu hal yang terlupakan bahwa masyarakat adat memiliki model pemerintahan yang otonom. Dengan demikian dapat dinyatakan bahwa secara logis, setiap kelompok masyarakat yang ada dalam wilayah Republik Indonesia sejak awal mempunyai otonomi sendiri dan bukan otonomi yang diberikan.Karena memiliki otonomi asli seperti Keondofoloan di Distrik Sentani maka masyarakat keondofoloan Sentani sudah berotonomi sejak dahulu bahkan pada masa pemerintahan kolonial Belanda sistem pemerintahan keondofoloan tersebut diakui dan dalam proses pemerintahan kolonial Belanda, pemerintahan keondofoloan difungsikan secara baik.

Dalam wawancara terhadap narasumber ketika penulis menanyakan mengapa dalam prosesnya akhir-akhir ini tidak terdapat terdapat ondofolo, dikatakan bahwa Ondofolo atau pengurus adat sering tidak memenuhi undangan yang diberikan. Mereka tidak ingin hadir karena terjadi perbedaan pendapat mengenai siapa pemilik tanah yang berhak atas ganti kerugian. Sehingga jika hal tersebut terus berlangsung maka akan menimbulkan sedikit konflik seperti pada: (a) tidak taat asas terhadap tata peraturan perundangan, (b) alat bukti kepemilikan tanah dan hak-hak tertentu yang ada di atas tanah, (c) asalusul kepemilikan tanah, (d) tingkat partisipatif pemilik tanah, (e) fungsi, nilai, dan makna tanah, (f) netralitas peran aparat, (g) sosialisasi dan keterbukaan dalam proses pengadaan tanah, (h) penentuan nilai jual tanah dan ganti rugi, dan (i) peranan pihak ketiga.

Menurut teori perlindungan hukum, berdasarkan ketentuan Pasal 43 Ayat (1) UU Nomor 21 Tahun 2001 yang menyatakan Pemerintah Provinsi Papua wajib mengakui, menghormati, melindungi, memberdayakan dan mengembangkan hak-hak masyarakat adat dengan berpedoman pada ketentuan peraturan hukum yang berlaku. Maka sudah sewajarnya jika pemerintah melakukan musyawarah dengar pendapat dengan masyarakat adat dan pengurus adatnya demi menjamin perlindungan terhadap hak-hak masyarakat adat. Sebagaimana gugatan yang telah dilayangkan oleh pemilik tanah mengenai siapa yang berhak dan besaran ganti kerugian dalam pengadaan tanahnya (Ondofolo).

Pada tanggal 02 Mei 2016 Ketua Panitia Pelaksanaan Pengadaan tanah (Kepala Kantor Kanwil BPN) mengeluarkan surat Validasi dengan nomor surat 504/11/91/VI/2016, yang pada pokoknya berisi bentuk ganti kerugian, data nominatif, luasan tanah pemilik tanah yang dibebaskan dan besaran ganti rugi yang harus dibayar. Sesuai dengan Pasal 112 ayat 1 Undangundang Nomor.02 Tahun 2012 tentang Pengadaan Tanah bagi Kepentingan Umum dan Pasal 76 ayat 4 Peraturan Presiden Nomor 99 Tahun 2014 tentang Perubahan Kedua Peraturan Presiden Nomor 71 Tahun 2012 Tentang Penyelenggaraan Pengadaan Tanah Bagi Pembangunan Untuk Kepentingan Umum yang pada pokoknya menyatakan bahwa pihak pengguna lahan dalam hal ini Bandar Udara Sentani wajib membayar ganti rugi tanah setelah 14hari kerja setelah diterima Validasi dari Ketua Panitia Pelaksana Pengadaan Tanah. Oleh karena itu bandar Udara sentani memohon pendapat hukum dari Kejaksaan Tinggi selaku Tim TP4D sebelum pelaksanaan ganti rugi tanah tersebut dilakukan. Berdasarkan teori advokasi dan penyelesaian sengketa melihat proses musyawarah dan bagian-bagian yang terlibat didalamnya maka advokasi yang dilalui menggunakan proses musyawaah dengan pimpinan adat dirasa telah cukup dan telah memenuhi ketentuan hukum formil sebagaimana yang tertuang dalam UU Nomor 2 Tahun 2012.

\section{Peran Atau Posisi OndofoloYang Seharusnya Dalam Pengadaan Tanah Bagi Kepentingan Umum Yang Berkeadilan}

Kepemimpinan Informal Ondofolo merupakan suatu gejala sosial, maka dalam kehidupan masyarakat Sentani sejak awal juga sangat membutuhkan kepemimpinan. Kehadiran pemimpin di tengah-tengah masyarakat Sentani menurut mitos yang ada pada hakikatnya merupakan utusan dari makro kosmos yang hadir di wilayah Sentani untuk menata tata kehidupan masyarakat secara baik menuju suatu tata 
kehidupan yang aman, tentram, harmonis, rukun, adil, makmur dan sejahtera lahir dan bathin.

Berkenaan dengan adanya mitos diatas, maka sumber kekuasaan pemimpin masyarakat Sentani (Ondofolo) berasal dari makro kosmos yang diwariskan secara turun temurun hingga saat ini.Meskipun sejak awal peradaban masyarakat Sentani masih boleh dikatakan tradisional dengan dalam berbagai keterbatasan namun dalam menata kepemimpinan masyarakat Sentani secara garis besar justru menerapkan prinsip-prinsip organisasi modern yang secara gamblang dapat diketahui dari adanya struktur organisasi kepemimpinan informal Ondofolo. Partisipasi sebagai kesediaan untuk membantu berhasilnya setiap program sesuai kemampuan setiap orang tanpa berarti mengorbankan kepentingan diri sendiri.

Partisipasi masyarakat dalam pembangunan adalah keterlibatan seluruh anggota masyarakat dalam berbagai kegiatan pembangunan yang dilaksanakan di desa dalam wilayah Distrik Sentani Kabupaten Jayapura yang tercermin dari keterlibatan masyarakat keterlibatan dalam perencanaan pembangunan, keterlibatan dalam pelaksanaan pembangunan, keterlibatan dalam penerimaan, pemanfaatan, pemeliharaan dan pengembangan hasil-hasil pembangunan serta keterlibatan dalam mengawasi dan menilai hasilhasil pembangunan.

Keberadaan desa dan pemerintah desa dengan sifat otonominya telah berubah dari otonomi asli menjadi otonomi pemberian, secara langsung maupun tidak langsung telah menciptakan suatu model ketergantungan yang permanen dari pemerintah desa kepada pemerintah tingkat atas. Akibat adanya ketergantungan yang demikian itu, di satu pihak pemerintah desa tentu kurang memperhatikan aspirasi masyarakat dan bahkan lebih loyal kepada pemerintah tingkat atas yang berwenang mengangkatnya. Terkait dengan kasus pengadaan tanah yang penulis teliti, peran serta ondofolo dalam penyelesaian ganti kerugian adalah mendukung program pemerintah terkait pengembangan bandara dengan mengijinkan pemerintah membangun terlebih dahulu dengan perjanjian dibayar 2 tahun kemudian dan pembangunan telah terlaksana. Sampai dengan rapat penentuan harga ganti rugi ondofolo masih dilibatkan. Pada tahapan selanjutnya ondofolo sudah tidak menyetujui proses sebab pemilik tanah setempat tidak mengakui peran ondofolo dalam proses tersebut sampai dengan pembayaran ganti rugi tanpa melibatkan ondofolo dalam penandatangan pelepasan hak.

Dengan tidak diikutsertakannya para tokoh adat seperti ondofolo, koselo, abhu akho, abhu afaa, akhona fafa dalam proses pengambilan keputusan baik dalam konteks penyelenggaraan pemerintahan maupun pelaksanaan pembangunan, mengakibatkan keterlibatan masyarakat dalam setiap kegiatan sangat minim sehingga sangat berpengaruh negatif terhadap peningkatan taraf hidup dan kesejahteraan masyarakat. Padahal sejak dahulu, sebelum ada desa, pemerintahan ondofolo sudah jauh berkembang dan diterima oleh semua lapisan masyarakat Distrik Sentani Kabupaten Jayapura (Kopeuw, P.M., 2014).

Selanjutnya dalam memimpin masyarakat keondofoloan Sentani, Ondofolo memiliki kewenangan yang luas meliputi:

a. Bidang Agama (religi), dalam praktiknya, ondofolo berperan selaku pemimpin upacara ritual, dan dalam kaitan dengan itu, Ondofolo merupakan mediator antara dunia nyata dan magis.

b. Dalam bidang ekonomi, Ondofolo memiliki kewenangan dalam dan menguasai dan mengwasi semua sumber daya alam yang ada untuk digunakan sebesar-besarnya bagi kemakmuran masyarakat keondofoloan.

c. Dalam bidang sosial, Ondofolo mempunyai kewenangan menerima sebagian harta maskawin dari setiap anak gadis yang kawin keluar kampung meskipun pada saatnya semua harta itu harus digunakan untuk kepentingan masyarakat.

d. Dalam bidang politik, Ondofolo berwenang mewakili kampungnya dalam berhubungan dengan kampung lain baik dalam mengatasi masalah antar kampung, maupun dalam menjalin kerjasama dengan kampung lain.

e. Dalam bidang peradilan, Ondofolo berperan sebagai hakim yang mengadili setiap pelanggaran adat yang terjadi.

Berkaitan dengan itu pula, berarti bahwa ondofolo mempunyai tugas dan tanggung jawab yang sangat berat yang pada hakikatnya adalah harus berupaya untuk mewujudkan masyarakat yang adil dan makmur termasuk juga dalam kasus pengadaan tanah untuk kepentingan umum dalam hal ini perluasan Bandar Udara Sentani ini. Ondofolo secara adat juga mengenai proses pengadaan tanah yang sedang berlangsung dengan 
ketentuan permasalahan yang ada haruslah diselesaikan di adat (Obhe) atau pendopo adat melalui sidang adat yang disaksikan seluruh lapisan masyarakat. Hal ini juga melindungi pemerintah apabila kelak di kemudian hari terjadi tuntutan dalam obyek yang sama oleh masyarakat yang sama. Yang terjadi sekarang ini proses diarahkan diluar adat. Kemungkinan yang terjadi nantinya akan terjadi banyak tuntutan liar dari masyarakat yang merasa memiliki hak yang sama. Obyek yang dibayar tersebut bukan tanah sertifikat namun tanah adat. Hal ini tidak akan terjadi apabila pembayaran melalui ondofolo dan terjadi di pendopo adat.

Berdasarkan teori keadilan, proses pengadaan tanah untuk kepentingan yang melibatkan tanah milik masyarakat adat diatas dan pengakuan dari Ondofolo selaku pemimpin yang selama ini bertanggung jawab secara penuh terhadap kelangsungan dan kesejahteraan hak-hak masyarakat adat dinilai kurang adil. Karena dalam penentuannya lebih didasarkan pada penilian data normatif sedangkan menurut pengakuan Ondofolo bahwa mereka bukanlah orang-orang yang berhak terhadap ganti kerugian tersebut. Sehingga dalam penentuan keputusan tersebut oleh masyarakat adat yang merasa dirugikan hingga saat ini masih menempuh upaya hukum untuk mendapatan keadilan yang sebenarnya. Sesuai dengan ketentuan Pasal 43 Ayat (5) UU Nomor 21 Tahun 2001 tentang OTSUS Papua.

Disadari dalam perkembangan masa kini, peran Ondofolo semakin dibatasi oleh kehadiran pemerintah, semua aspek kehidupan diurus oleh pemerintah. Campur tangan pemerintah yang demikian dominan itu, pada gilirannya mengambil alih bidang kewenangan, tugas yang semula merupakan tanggung jawab Ondofolo. Ondofolo kini memang masih terlihat hanya berperan dalam urusan adat istiadat. Undang-undang Nomor 55 Tahun 2001 tentang Otonomi Khusus Untuk Provinsi Papua meskipun disebut Otonomi Khusus yang salah satu esensinya adalah memeberikan peluang guna menghidupkan kembali berbagai asosiasi lokal yang ada di Papua namun dalam praktik belum secara utuh dilaksanakan karena pola orientasi dan perilaku aparat pemerintah yang lebih berperan sebagai tuan yang harus dilayani daripada melayani masyarakat.

Pemerintahan Keondofoloan yang merupakan pemerintahan otonom yang asli dan yang tumbuh dan berkembang sejak dahulu jauh sebelum kemerdekaan Indonesia, dalam praktiknya sangat legitimited dan mendapat pengakuan dari seluruh masyarakat keondofoloan. Tumbuh, berkembangnya dan masih tetap terpeliharanya pemerintahan keondofoloan merupakan konsekwensi logis dari adanya keanekaragamannya budaya, etnik (kebhinekaan).

Mencermati adanya nilai-nilai adat yang masih dipegang teguh oleh masyarakat keondofoloan di Distrik Sentani, dengan semangat otonomi daerah yang luas, nyata dan bertanggung jawab sesuai amanat Undang-undang Nomor 22 Tahun 1999, maka selayaknya pemerintah memberikan peluang bagi tumbuh dan berkembangnya sistem pemerintahan keondofoloan di Distrik Sentani.

Dalam pemerintahan keondofoloan yang merupakan suatu lembaga yang dapat dikatakan masih bersifat tradisional, namun ternyata hingga kini masih sangat dipegang teguh oleh masyarakat adat setempat manakala pemimpin/ondofolo dalam melaksanakan kepemimpinannya sangat berwibawa, mempunyai kewenangan yang luas dan sangat konsisten dalam memajukan kesejahteraan anggota masyarakat adat dalam berbagai aspek kehidupannya yang dalam praktiknya kekuasaan dilaksanakan oleh suatu badan dengan pembagian tugas yang jelas sehingga dapat mempengaruhi tingkah laku orangorang supaya dapat bekerja sama dalam mewujudkan tujuan yang disepakati bersama. Dimanadidapati pula informasimengenai keinginan dan harapan ondofolo bagi kelangsungan adat masyarakat tersebut. Karena bagaimanapun Ondofolo adalah raja di wilayah adat tersebut, seorang raja pasti ingin bagaimana mensejahterakan masyarakatnya. Jadi harapan ondofolo adalah keselarasan pembangunan di wilayah adat dengan memperhatikan hak asli masyarakat adat dan untuk kesejahteraan masyarakat. Ondofolo sebagai penguasa adat ingin siapa saja yang akan membangun di wilayah mematuhi hukum adat yang berlaku di daerah dan semua masyarakat mematuhinya.

Uraian yang ada menunjukan secara jelas bahwa dalam kelompok masyarakat adat Sentani, Ondofolo selaku pemimpin masyarakat dalam melaksanakan kepemimpinannya selalu berupaya meningkatkan taraf hidup setiap anggota masyarakat adat Sentani. Sehubungan dengan itu, Ndraha, T (2001)menyatakan "kepemimpinan adalah gejala sosial". Berdasarkan hal tersebut, 
sesuai dengan peradaban masyarakat adat Sentani, pada hakikatnya merupakan suatu organisasi yang mempunyai tujuan tersendiri dan sekaligus mempunyai pemimpin yang berwenang dan bertugas membangun dan memajukan masyarakat adat Sentani menuju tercapainya tujuan yang dikehendaki bersama, Ondofolodalamhalini juga menyampaikan saran terkait kasus-kasus dengan pemerintah yang belum diatur dalam undangundang. Undang-undang pengadaan tanah secarahakikatnyamemang mengatur penerima hak adalah masyarakat langsung dan tidak melalui perwakilan namun untuk kasus di sentani yang masih merupakan tanah adat musti ada peraturan pemerintah lagi yang mengatur proses adat. Seyogyanyajangan sampai malah menyulitkan pemerintah dalam membangun di tanah Papua. Perlu Peraturan daerah juga yang jelas mengatur kepemilikan hak atas tanah adat atau pengakuan pemerintah tentang struktur adat dalam bentuk PERDA sehingga seluruh lapisan masyarakat tahu hukum dan peraturan adat dan pemerintah dan berjalan bersandingan.

Makadariitu, berarti bahwa disatu pihak kekuasaan Ondofolo sangat luas tetapi dalam praktiknya justru ada suatu badan yang melaksanakan kekuasaan dengan pembagian tugas yang jelas. Jadi disini ada delegasi kewenangan sehingga dapat dikatakan ada pemusatan kekuasaan disatu pihak tetapi dilain pihak ada pemencaran kekuasaan. Sehingga berdasarkan teori peran serta, sejatinya Ondofolo dalam implementasi perannya diletakkan pada semua tataran. Mulai dariproses sejak perencanaan hingga penyerahan penggunaan tanah untuk kepentingan umum, dalam bentuk: (a) sosialisasi, (b) penghubung antar system, (c) mediasi, dan (d) pendampingan.

Perandanfungsi pimpinan adat suku-suku sedikit teralihkan oleh adanya unsur kepemimpinan dari Pemerintahan. Sehingga otonomikhusus yang telah diciptakan untuk Provinsi Papua tidak dapat berjalan dengan sebaiknya bersamaan dengan masyarakat adat dan segala bentuk kepemimpinannya.

\section{DAFTAR RUJUKAN}

Cahyo, B.T. 1983. Ekonomi Pertanahan. Yogyalarta: Liberty

Harsono, B. 2005. Hukum Agraria Indonesia, Sejarah Pembentukan Undang-Undang Pokok Agraria, Isi dan Pelaksanaan-

\section{SIMPULAN}

Proses pemberian ganti rugi dalam pengadaan tanah untuk kepentingan umum dalam perluasan bandar udara sentani tidak mengabaikan peran serta ondofolo. Ondofolo menarik diri dalam prosesnya karena menurut pendapat Ondofolo terdapat kekeliruan dalam keputusan tentang siapa saja yang berhak terhadap ganti kerugian pengadaan tanah untuk kepentingan umum tersebut. Kekeliruan tersebut karena pemerintah menggunakan data yang tidak memiliki tanda tangan Kepala Distrik, kepala Kampung dan ondofolo. Hal tersebut yang menjadi penyebab gugatan ke pengadilan hingga saat ini.

Implikasi Hukum Jika Ondofolo Tidak Dilibatkan Dalam Proses Pemberian Ganti Rugi Atas Pengadaan Tanah Untuk Kepentingan Umum Pada Perluasan Bandara Udara Sentani Di Provinsi Papua adalah dianggap melakukan pelanggaran terhadap ketentuan Pasal 43 UU Nomor 21 Tahun 2001 tentang Otsus Papua yang melindungi hak-hak masyarakat adat melalui kepengurusan ketua adat dalam hal ini Ondofolo, dimana tidak dihormatinya aturan-aturan adat setempat sepanjang tidak bertentangan dengan konstitusi Negara. Sehingga keputusan pemerintah akan dianggap tidak sah karena dalam prosesnya tidak mendapat persetujuan dari Ondofolo. Hal tersebut akan mengakibatkan lemahnya keputusan pemerintah karena tidak mendapat persetujuan dari dewan adat di Papua.

Peran Atau Posisi Ondofolo Yang Benar Dalam Pengadaan Tanah Bagi Kepentingan Umum Demi Keadilan adalah sebatas mempengaruhi tingkah laku orang-orang supaya dapat bekerja sama dalam mewujudkan tujuan yang disepakati bersama demi terciptanya keadilan dan terjaminnya hak-hak masyarakat adat baik secara adat maupun secara konstitusional Republik Indonesia selama tidak melanggar aturan yang berkaitan

nya. Edisi Revisi. Jakarta: Djambatan

Harsono, B. 2013. Hukum Agraria Indonesia : Himpunan Peraturan-Peraturan Hukum Tanah. Jakarta : Penerbit Universitas Trisakti 
Kelsen, H. 1961.General Theory of law in state. New York: Russel \& Russel

Kopeuw, P.M. 2014. Sentani menanti Pelangi (Suatu kajian refleksi dan perenungan). Cetakan III. Jayapura Papua: Arika Publisher.

Ndraha, T. 2001. Kybernologi. Jakarta : PT. Rineka Cipta.

Santoso, U. 2012. Hukum Agraria Kajian Komprehensif. Jakarta: Kencana

Sitorus, O. \& Sebayang, B., Konsolidasi Tanah perkotaan : Suatu Tinjauan Hukum, Yogyakarta: Mitra kebijakan Tanah Indonesia

Sudiyat, I. 1978. Asas-Asas Hukum Adat. Yogyakarta: Liberty

Sugiharto, U.S. 2015. Hukum Pengadaan tanah, Pengadaan Hak atas tanah untuk Kepentingan Umum Pra dan Pasca Reformasi. Malang: Bayumedia

Sutedi, A. 2011. Good Corporate Governance. Jakarta: Sinar Grafika.

Yamin, M. 1971. Naskah Persiapan UUD 1945 Jilid Pertama. (ctk.kedua). Jakarta: Siguntang
Peraturan Kementerian Dalam Negeri Nomor 72 Tahun 2012 yang dimuat dalam Berita Negara Republik Indonesia Nomor 1120, Tahun 2012

Peraturan Kementerian Keuangan Nomor 13 Tahun 2013 yang dimuat dalam Berita Negara Republik Indonesia Nomor 27, Tahun 2013

Peraturan Kepala Badan Pertanahan Nasional Nomor 5 Tahun 2012 yang dimuat dalam Berita Negara Republik Indonesia Nomor 19, Tahun 2012

Peraturan Presiden Nomor 71 Tahun 2012 tentang Penyelenggaraan Pengadaan Tanah Untuk Kepentingan UmumDimuat dalam Berita Negara Republik Indonesia Nomor 45, Tahun 2012

Undang-Undang Nomor 2 Tahun 2012 tentang Pengadaan Tanah Untuk Kepentingan Umumyang dimuat dalam Lembaran Negara Nomor 22, Tahun 2012

Undang-Undang Nomor 5 Tahun 1960 Tentang Pokok-Pokok AgrariadalamLembaran Negara Nomor 104 Tahun 1960, Penjelasan dalam Tambahan Lembaran Negara Republik Indonesia Nomor 2043 